\title{
HYDROLOGICAL MODELING IN THE MANAS RIVER BASIN USING SOIL AND WATER ASSESSMENT TOOL DRIVEN BY CMADS
}

\author{
Xianyong Meng, Hao Wang, Xiaohui Lei, Siyu Cai, Hongjing Wu, Xiaonan Ji, Jianhua Wang
}

Original scientific paper Hydrological simulation in meteorological ungauged areas has always been a difficult problem for the study on atmospheric and hydrological coupling; meanwhile, it is also one of the important factors that restrict model development and basin water resource knowledge. To analyze the mechanism of atmospheric and hydrological coupling, this study quantitatively evaluated water cycle situation in basins covered with glaciers and snow, and chose the Manas River Basin (MRB) in China as the typical research area to verify the adaptability of the China Meteorological Assimilation Driving Datasets for the Soil and Water Assessment Tool model (CMADS). The SWAT model was firstly built to simulate water resources, then we calibrated the model with CMADS dataset and started localization in the Manas River Basin (MRB), China, and finally calibrated simulated runoff with observed data SWAT-CUP (SWAT Calibration and Uncertainty Programs). In addition, parameter sensitivity analysis, and parameter calibration and validation were also included in the present study. Results showed that the SWAT model could well reproduce the runoff process of two stations (Kenswat and Hongshanzui) in the research area by using data from CMADS. The simulation performed well on monthly scale in both stations, where $R^{2}=(0,556 \div 0,999)$ and $N S E=$ $(0,937 \div 0,998)$, and also showed satisfactory effects, where $R^{2}=(0,927 \div 0,993)$ and $N S E=(0,836 \div 0,997)$.Our research suggests that the SWAT model can show satisfactory results through parameter calibration in areas with high glacial recharge rate. Moreover, CMADS can provide necessary meteorological data for SWAT simulations, and support parameter calibration and historical surface data analysis.

Keywords: CMADS; SWAT; the Manas River Basin (MRB)

Hidrološko modeliranje u porječju rijeke Manas primjenom alata za procjenu tla i vode pomoću CMADS-a

Izvorni znanstveni članka

Hidrološka simulacija u meteorološki neispitanim područjima oduvijek je težak problem u proučavanju atmosferskih i hidroloških odnosa; to je također jedan od važnih faktora koji ograničavaju razvoj modela i spoznaju o izvoru vode u porječju. U svrhu analize atmosferskih i hidroloških odnosa; u radu se daje kvantitativna procjena promjene vodotokova u porječjima prekrivenim ledenjacima i snijegom, te je izabrano porječje rijeke Manas (Manas River Basin - MRB) u Kini kao tipično područje istraživanja u svrhu provjere prilagodljivosti meteoroloških podataka u Kini (China Meteorological Assimilation Driving Datasets) - CMADS, za model alata za procjenu tla i vode - Soil and Water Assessment Tool model (SWAT). Taj se model prvenstveno koristio za simulaciju izvora vode, a zatim smo ga kalibrirali s podacima CMADS-a, lokalizirali u porječje rijeke Manas (MRB), Kina, te konačno kalibrirali simulirano oticanje s dobivenim podacima SWAT-CUP (SWAT Calibration and Uncertainty Programs). Uz to, u ovo je istraživanje također uključena analiza osjetljivosti parametara te ocjena i kalibriranje parametara. Rezultati su pokazali da se modelom SWAT može dobro reproducirati proces oticanja vode na dva položaja istraživanog područja (Kenswat i Hongshanzui) primjenom podataka iz CMADS-a. Simulacija se pokazala uspješnom na osnovu podataka od mjesec dana na oba položaja gdje su $R^{2}=(0,556 \div 0,999)$ i $N S E=(0,937 \div 0,998)$, i dala zadovoljavajuće rezultate kod $R^{2}=(0,927 \div 0,993)$ i $N S E=(0,836 \div 0,997)$. Naše istraživanje pokazuje da se modelom SWAT mogu dobiti zadovoljavajući rezultati kalibriranjem parametara u područjima s visokim dotokom vode s vodenjaka. Uz to, CMADS može osigurati potrebne meteorološke podatke za SWAT simulacije i pomoći kod kalibriranja parametara i analize prikupljenih podataka s površine.

Ključne riječi: CMADS; porječje rijeke Manas (MRB); SWAT

\section{Introduction}

Water resource is a scarce and valuable resource, for which good water resource management, can lead to its better development. However, due to the complexity and uncertainty, water resource management has become a challenge for its improvement particularly in arid and cold areas. Hydrological models are very important due to their great significance for better utilizing current hydrological theories for improving or creating new management strategies. Although hydrological models have been widely used in regional water resources simulation, there are still several difficulties when applied in practical applications. For example, the simulation of ice and snow resources which are covered by the alpine mountains is still problematic water resources simulation all over the world.

The restrictions of the simulation process are mainly reflected in two aspects. Firstly, a well performed and widely verified model should greatly reduce the errors and uncertainty of simulations, whereas the uncertainty would increase when the superposition error happens. In the development process from conceptual models to distributed hydrological models, the empirical errors and uncertainty of the models are both decreasing, and SWAT is a popular and widely used distributed hydrological model among these models. Secondly, the uncertainty of the model atmospheric driving input would greatly increase the uncertainty of the output of hydrological models, so that it is necessary to use a higher resolution forcing data (e.g., the China Meteorological Assimilation Driving Datasets for the Soil and Water Assessment Tool model (CMADS)) to drive a mature hydrological model (SWAT) for achieving the reliable results.

\section{State of the art}

SWAT was selected for simulation in this research. This model is widely applied all over the world especially in catchment simulation modeling, and also adopted by hydrologists to solve catchment hydrological issues and non-point pollution $[1 \div 6]$. Besides, it has been extensively used to evaluate the influences of land use, climate change, and land management decision-makings on watershed dynamics $[7 \div 12]$ and to forecast the sediment loads on various watershed scales $[13 \div 18]$. Luo et al. [19] applied SWAT in the Manas River Basin (MRB) to simulate the stream flow dominated by glaciers 
and/or snow melt, and found that the stream flow receded quickly during flood season but slowly in dry season in rivers in the cold and arid areas in northwest China. Ji et al. [20] used SWAT to analyze the effects of precipitation/temperature input on snow accumulation in glacier and snow areas of the Manas River Basin (MRB), and discovered that precipitation had a great influence on snow accumulation and glacier melting.

Temperature not only impacts runoff time but also affects total amount of water yield. Since the glacier/snow dominated Manas River makes the situation more complex, it is necessary to validate whether SWAT is suitable for this basin if only using temperature index methods. Furthermore, western areas in China have few meteorological stations compared with Southeastern China, and hence CMADS developed by our team may provide an accurate meteorology for SWAT. The main objective of this research is to clarify whether or not SWAT driven by CMADS can simulate water discharge (mainly snowmelt runoff) reasonably in the Manas River, Xinjiang, China.

The remainder of this study is organized as follows. In Section 3, the study scope, method and input data are introduced. In Section 4, SWAT is driven by CMADS and sensitivity analysis is carried out, from which sensitive parameters and the final validation simulation results are obtained. Finally, some conclusions are given in Section 5.

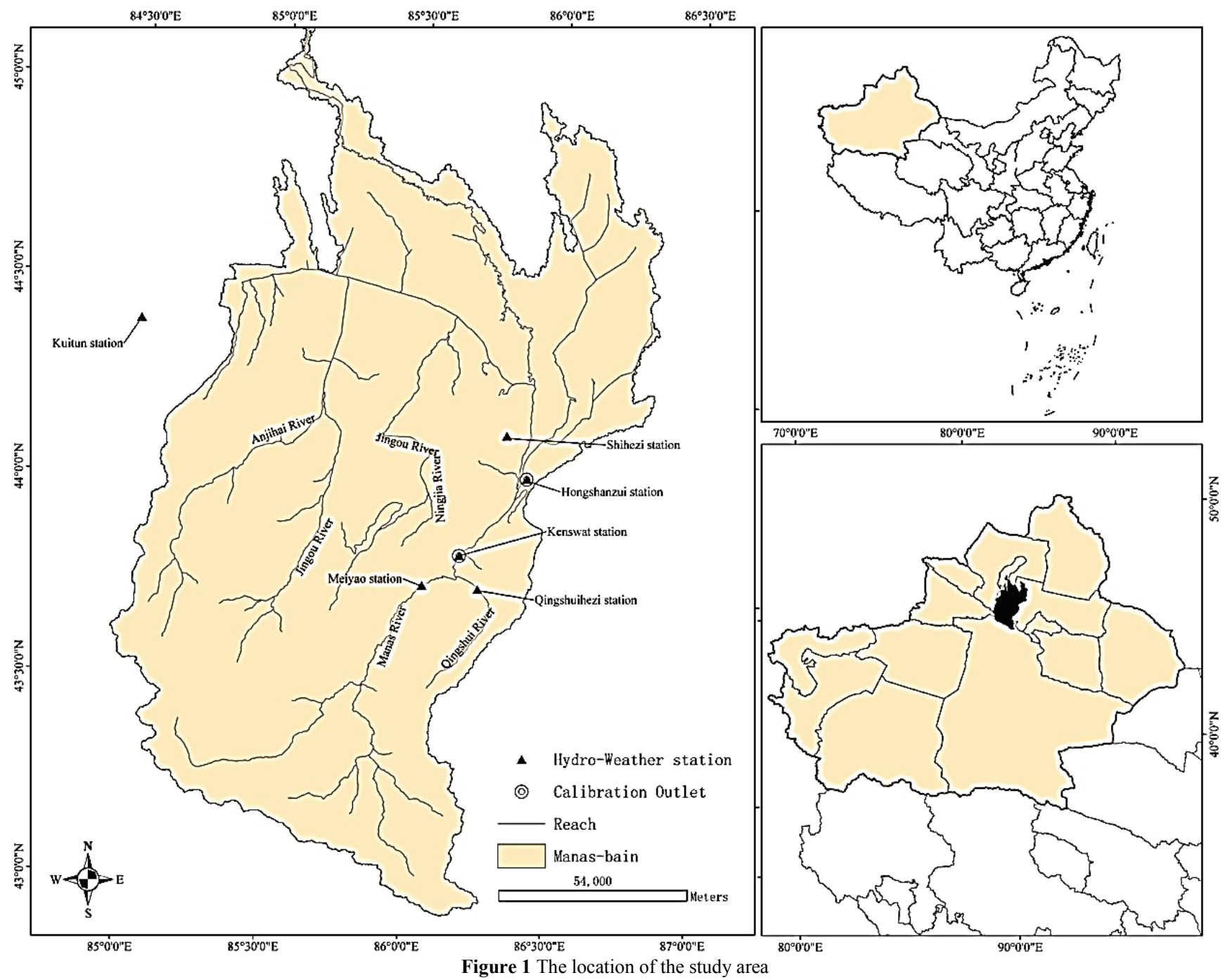

\section{Methodology}

\subsection{Study area}

The Manas River Basin (MRB) $\left(43^{\circ} 27^{\prime} \div 45^{\circ} 21^{\prime} \mathrm{N}\right.$, $\left.85^{\circ} 01^{\prime} \div 86^{\circ} 32^{\prime} \mathrm{E}\right)$ is located between the northern foothills of Tian-shan mountain chain and the north of the Junggar Basin, China (Fig. 1). The length of the basin is $260,8 \mathrm{~km}$ from south to north and $198,7 \mathrm{~km}$ from east to west, and the total area is $31000 \mathrm{~km}^{2}$. The basin has the highest height above sea level of 5242,5 $\mathrm{m}$ and the lowest height of $256 \mathrm{~m}$ in the Manas Lake, with an average height of $3022 \mathrm{~m}$. The land whose elevation is higher than $3600 \mathrm{~m}$ above mean sea level is covered with glaciers and snow all year round, which serves as the main water resources of the Manas catchment [21]. The area of glaciers is $608,25 \mathrm{~km}^{2}$ and the melt-water and rain are the main sources of runoff [22]. The major landscape of the Manas catchment can be described as an oasis-mountaindesert system. On areas whose elevation is lower than 800 $\mathrm{m}$, the land is covered by desert and oasis and the sand of Quaternary loess. On areas whose elevation is between $800 \mathrm{~m}$ and $1100 \mathrm{~m}$, the surface is distributed by grassland (such as Ceratocarpus arenarium and Helichrysum arenarium). On areas whose elevation is between $1100 \mathrm{~m}$ and $1650 \mathrm{~m}$, the land is distributed by mountain grassland (e.g., Phlomis Linn and Polygonum L), while land with 
elevation between $1650 \mathrm{~m}$ and $2850 \mathrm{~m}$ is covered by forest land (e.g., Picea schrenkiana), and areas with elevation from $2850 \mathrm{~m}$ to $3200 \mathrm{~m}$ are distributed by mountain meadow (e.g., Caragana jubata, Labiatae). The highest area with elevation from $3200 \mathrm{~m}$ to $3900 \mathrm{~m}$ is distributed by sparse mountain vegetation and tundra (e.g., Cladonia humilis).

There are five rivers in the Manas catchment, from east to west, including the Manas River, the Jingou River, the Tacitus Creek, the Ningji River and the Ba Yinggou River. The source of these rivers is the Tian-shan Mountains (Fig. 1). The river discharge in the Manas catchment is $2290 \times 10^{6} \mathrm{~m}^{3}$ and the total volume of water resources is about $2573 \times 10^{6} \mathrm{~m}^{3}$ [22]. As mentioned above, snow and glaciers are the main sources of water for the low land of the Tian-shan Mountains [23]. The agricultural production in this area uses a large amount of river water derived from glacier melt [24].

The climate of the Manas watershed is continental drought, with chilly winters, and hot summers. The average temperature is $6,6{ }^{\circ} \mathrm{C}$ in the oasis-desert, the average annual precipitation ranges from $110 \mathrm{~mm}$ to 300 $\mathrm{mm}$ and the evaporation varies between $1500 \mathrm{~mm}$ and $2000 \mathrm{~mm}$ [25].

\subsection{SWAT}

The SWAT model was firstly proposed by Dr. Jeff Arnold from the Agricultural Research Service (ARS) of the United States Department of Agriculture (USDA), whose initial purpose was to forecast the long-term influences of land management on water and chemical substances under the condition of changing soil types, land use types and management measures in large basins. SWAT is a distributed hydrological model based on GIS and computes on daily scale. The catchment discretization in SWAT is operated from a given Digital Elevation Model (DEM) to a number of sub-basins [26, 27]. The Hydrologic Response Units (HRUs) in each sub-basin is regarded as basic model units, with similar land use types and soil types. The hydrological processes of evapotranspiration, infiltration, surface runoff, groundwater flow and sediment erosion are simulated in each HRU. Runoff from each HRU is firstly converged to the main canal of each sub-basin, then flows from one sub-basin to another, and finally reaches the catchment outlet. The flow concentration is usually computed with variable storage routing method [28] or Muskingum method.

The water balance equation can be expressed as follows:

$$
S W_{t}=S W_{0}+\sum_{i=1}^{t}\left(R_{\text {day }}-Q_{\text {surf }}-E_{\mathrm{a}}-w_{\text {seep }}-Q_{\mathrm{gw}}\right),
$$

where $S W_{t}$ is the final soil water content $(\mathrm{mm}), S W_{0}$ is initial soil water content $(\mathrm{mm}), t$ is the simulation time (days), $R_{\text {day }}$ is the amount of daily precipitation $(\mathrm{mm}$ $\left.\mathrm{H}_{2} \mathrm{O}\right), Q_{\text {surf }}$ is the amount of daily surface runoff $(\mathrm{mm}$ $\left.\mathrm{H}_{2} \mathrm{O}\right), E_{\mathrm{a}}$ is the amount of daily evapotranspiration (mm), $w_{\text {seep }}$ is the amount of water entering into the vadose zone from the soil profile on a given day $(\mathrm{mm})$, and $Q_{\mathrm{gw}}$ is the amount of return flow on a given day $(\mathrm{mm})$.

The soil interflow characteristics in SWAT are calculated using the kinematic storage models, which include the topographical slope, the soil hydraulic conductivity (Sol_K) and the temporal and spatial changes of soil moisture. Lateral flow is important in catchments with soil that has high hydraulic conductivity in surface layers. Sloan et al. [29] incorporated SWAT with a kinematic storage model for subsurface flow by calculating percolation at the same time. Then the shallow aquifer converges groundwater to the main channels within the sub-basin. Surface runoff is the amount of rainfall left after interception and infiltration. The amount of surface runoff is estimated with the Green \& Ampt infiltration method [30] and the Soil Conservation Service (SCS) curve number procedure [31]. The peak runoff rate reflects the erosive power of a storm and can be used for predicting sediment losses. Evapotranspiration includes the transformation processes of water form liquid to vapor, such as plant canopy evaporation, transpiration, soil evaporation and sublimation. Many methods have been proposed to simulate the potential evapotranspiration (PET), among which the Priestley-Taylor method [32], the Penman-Monteith method [33] and the Hargreaves method [34] have been incorporated into SWAT. This study selected Hargreaves method to simulate PET.

\subsection{Input data}

The spatial data were obtained by using the ArcSWAT interface that permits the model input from the grid digital model. The input data included: land use data, soil data, digital elevation model (DEM) data and meteorological data.

\subsubsection{Land use data}

The data were obtained from the National Natural Science Foundation of Environmental and Ecological Science Data Center. Land cover may influence the runoff generated by precipitation.

\subsubsection{Soil data}

The soil data were obtained from the Soil Information System (SIS) of China, which were provided by the Institute of Soil Science, Chinese Academy of Sciences.

\subsubsection{DEM data}

This study used the ASTER GDEM (Edition 1) data with a resolution of $30 \times 30 \mathrm{~m}$. Pretreatment was carried out to decrease errors in flat region with no streams or flow direction. A grid resolution of $30 \mathrm{~m}$ was adopted to calculate the physical characteristics of the basin. Arc map was used to generate the basin and sub-basin boundaries, stream network, slope, land cover and soil occupation layers.

\subsubsection{Meteorological data}

CMADS for the SWAT model of Version 1.1 were used to provide meteorological data [35]. SWAT automatically read the data from nearly 40 stations, which included over 200 meteorological elements (e.g., rainfall, temperature, relative humidity, solar radiation and wind speed data) (See Fig. 2b). 


\section{Result analysis and discussion}

According to the natural river network, the distribution of precipitation stations and the topography, the study area (the Manas catchment) was divided into 101 natural sub-basins (See Fig. 2a). Based on observed runoff at the Hongshanzui station, SWAT was calibrated and validated. In order to obtain a high resolution for land use, soil properties and management practices, these subbasins were further divided into 1920 HRUs. On this basis, simulations using SWAT on annual and monthly scales were conducted successively so as to make SWAT reproduce the discharge stream more reasonably.

This research conducted surface runoff simulation between 1977 and 2007 in the Manas River Basin (MRB).
The data from 1981 to 1994 were used for calibration, and those from 1995 to 2007 were for validation. Three years (from 1977 to 1980) of warm-up period were set to initialize SWAT in this study. Fig. 4 and Fig. 6 illustrate the calibration and validation processes of observed and simulated monthly runoff data at two hydrological stations (Kenswat and Hongshanzui) from 1981 to 2007. In general, the runoff simulated using SWAT model follows a similar trend with the observed one, and the timings of flood occurrence for both simulated and observed stream data match well. In most cases, the order of magnitude of the runoff peaks reasonably accords with the recession curves, but the flood from snowmelt runoff is not well characterized and not correctly represented.
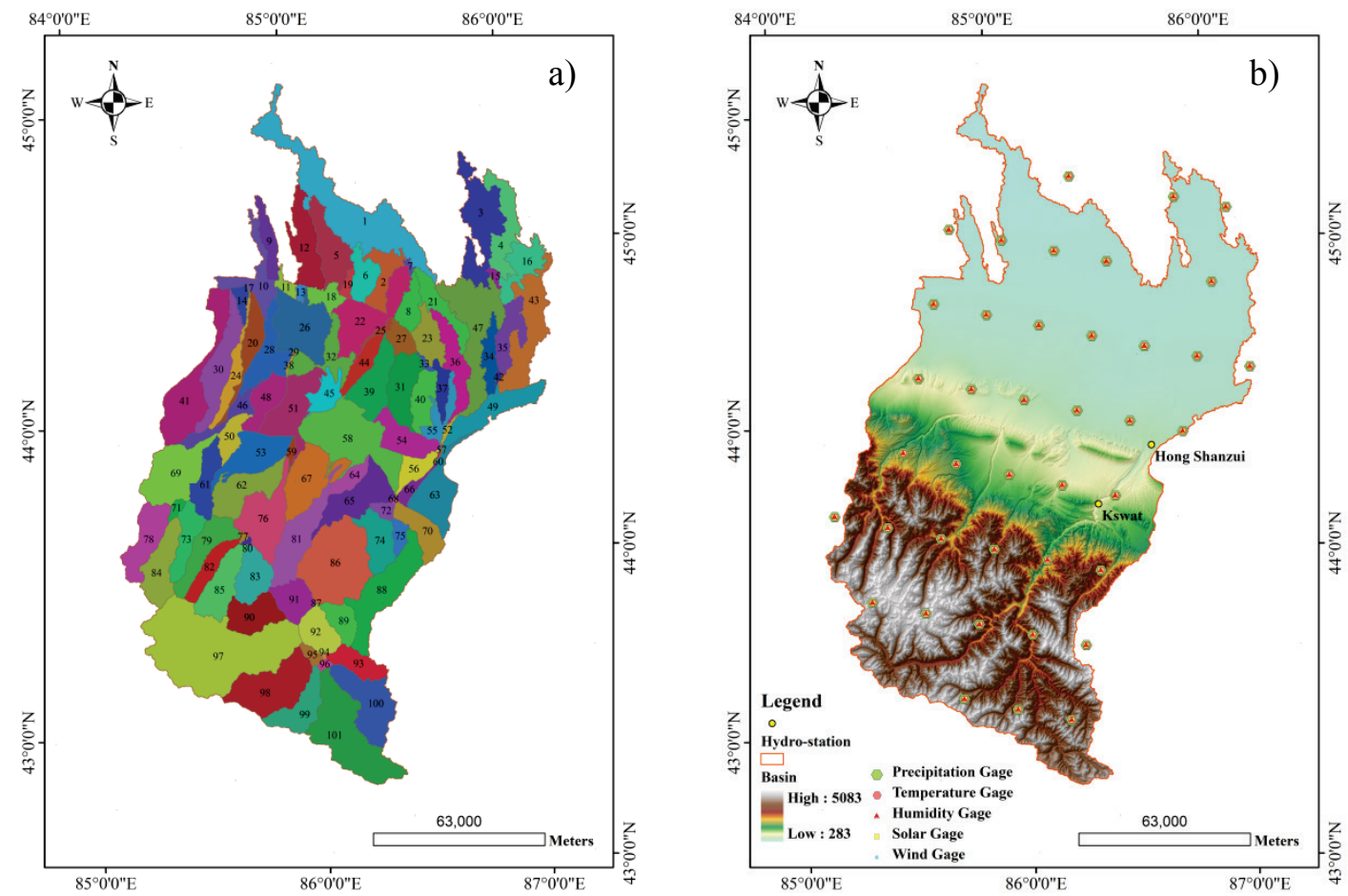

Figure 2 a) Delineation of the Manas River Basin (MRB) into 101 sub-basins; b) CMADS data distribution in the Manas River Basin (MRB)

Table 1 Ranking of the most sensitive parameters and their variation ranges for auto-calibration

\begin{tabular}{|c|l|c|c|c|}
\hline Parameter & \multicolumn{1}{|c|}{ Description } & Min & Max & Value adopted \\
\hline SOL_Z & Depth from soil surface to bottom of layer $(\mathrm{mm})$ & $-25 \%$ & $25 \%$ & 12,343 \\
\hline GWQMN & Threshold water depth in the shallow aquifer for flow $(\mathrm{mm})$ & 0 & 5000 & 0,01 \\
\hline CN2 & the moisture condition II curve number & 30 & 70 & 35 \\
\hline SOL_AWC & Available water capacity $\left(\mathrm{mm} \mathrm{H}_{2} \mathrm{O} / \mathrm{mm}\right.$ soil) & $-0,04$ & 0,04 & 0,0132 \\
\hline CANMX & Maximum canopy storage $(\mathrm{mm})$ & 0 & 10 & 0,0225 \\
\hline SOL_K & Saturated hydraulic conductivity $(\mathrm{mm} / \mathrm{hr})$ & $-10 \%$ & $10 \%$ & 18,453 \\
\hline TIMP & Snow temperature lag factor & 0,055 & 3,11 & 0,060 \\
\hline SFTMP & Snowfall temperature $\left({ }^{\circ} \mathrm{C}\right)$ & $-3,0$ & 5,0 & $-0,213$ \\
\hline SMTMP & Snow melt base temperature $\left({ }^{\circ} \mathrm{C}\right)$ & 0,0 & 5,0 & 0,144 \\
\hline SMFMN & Melt rate for snow on June $21^{\text {st }}\left(\mathrm{mm} /{ }^{\circ} \mathrm{C}\right.$ day) & 0,0 & 2,5 & 0,125 \\
\hline SMFMX & Melt rate for snow on December $21^{\text {st }}\left(\mathrm{mm} /{ }^{\circ} \mathrm{C}\right.$ day) & 2,5 & 4,5 & 0,100 \\
\hline Ch_K $(2)$ & Effective hydraulic conductivity of channel $(\mathrm{mm} / \mathrm{hr})$ & 0,33 & 22,91 & 0,827 \\
\hline
\end{tabular}

\subsection{Sensitivity analysis}

The study carried out sensitivity analysis to determine the most sensitive parameters. This process would identify the parameters that have significant influences on the simulated snowmelt runoff. The sensitivity analysis was carried out by incorporating LH-OAT (Latin
Hypercube Sampling) in the SWAT2009, as given in Tab. 1. The calibration compares the measured runoff and simulated result by changing the sensitive parameters, and obtains the final validation simulation results [36].

The variation ranges of the parameters considered in the auto-calibration results are given in Tab. 1. The lower and upper bounds of Sol_Z, GWQMN, CANMX, TIMP 
and $\mathrm{CH} \mathrm{K}(2)$ were selected according to the default values by SWAT-CUP [37, 38]. The surface runoff was affected by the parameters including the curve number (CN2) and the available soil water capacity (SOL_AWC). $\mathrm{CN} 2$ is used to compute the depth of accumulated stream or precipitation excess. SOL AWC is the plant available water content when the soil is at the field capacity. Other parameters which impact the catchment responses were also considered for the calibration, including the maximum canopy storage (CANMX), the saturated hydraulic conductivity of the soil (SOL K), the snow temperature lag factor (TIMP), the snowfall temperature (SFTMP), the snow melt base temperature (SMTMP), the melt rates for snow (SMFMN and SMFMX), and the effective hydraulic conductivity of channel (Ch_K (2)).

\subsection{Model calibration and validation}

An automatic calibration procedure implemented in SWAT-CUP called SUFI-2 was applied in this study. This method used Bayesian framework to determine the uncertainties with a sequential fitting process in which iteration and unknown parameter estimates are achieved before final estimates. It considers uncertainties of model input, structure, parameters and observed data. Besides, this study adopted the Global Sensitivity analysis method (using t-Stat and p-Value to assess sensitivity) during the calibration process to avoid the equifinality phenomenon, which means several different parameter settings leading to acceptable hydrographs. The T-stat measures sensitivity with larger absolute values while the P-value considers zero value to determine sensitivity [37]. Based on thorough review of evaluation methods, Moriasi proposed four quantitative statistics that could be used to assess model performance in catchment simulation [39]: the Nash-Sutcliffe coefficient (NSE), the Relative root mean square error (RRMSE), the Percent bias (PBIAS) and the goodness-of-fit $\left(R^{2}\right)$.These four performance metrics of numerical model aim to match a simulated series with a measured time series. Note that NSE is a statistic method that quantifies the relative magnitude of the residual variance compared to the variance of the observed data [40], RRMSE is also used to search the optimal model parameters during the auto-calibration period (Tab. 2)
The closer the values of NSE and $R^{2}$ to the unity and the closer the value of RRMSE to zero, the better the performance of SWAT can be achieved. Percent bias $(P B I A S)$ represents the average tendency of the simulated data smaller or larger than their measured counter parts[41], and zero value of PBIAS represents an exact simulation. Moriasi proposed that model simulation could be assessed as a satisfactory one if RRMSE $<0,7, N S E>$ 0,5 , and $P B I A S$ is within $\pm 25 \%$ for runoff simulations on monthly scale. Here, we adopted the criteria (Tab. 3) developed by Moriasi [39].

As the above content mentioned, the entire Manas River Basin (MRB) was divided into 101 subbasins and 1920 HRUs, and the catchment was delineated using ArcMap interface of SWAT (ArcSWAT 2009) as shown in Fig. 2a. The area of the watershed is 202636,53 ha. The soil distribution map and land cover map are clipped to the watershed area to define the soil type and land use type of each HRU.

Table 2 Equations used for calculating these four performance metrics of numerical model

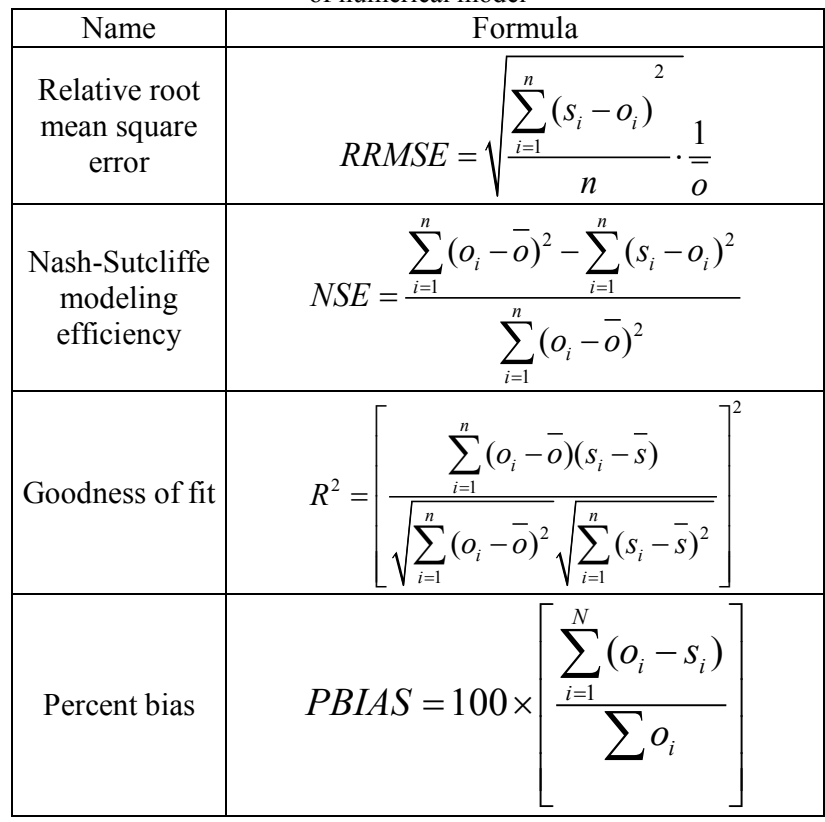

Note: $O_{i}$ - Measured runoff $\left(\mathrm{m}^{3} / \mathrm{s}\right), S_{i}$ - Simulated runoff $\left(\mathrm{m}^{3} / \mathrm{s}\right), \bar{O}$ - Mean measured runoff during simulation period $\left(\mathrm{m}^{3} / \mathrm{s}\right)$

\begin{tabular}{|} 
Table 3 Performance rating for recommended statistics \\
\begin{tabular}{|c|c|c|c|}
\hline Rank & $N S E$ & $P B I A S$ & $R R M S E$ \\
\hline Very good & $1,00 \geq N S E \geq 0,75$ & $|P B I A S|<10$ & $0,00 \leq R R M S E \leq 0,50$ \\
\hline Good & $0,75 \geq N S E \geq 0,65$ & $15 \geq|P B I A S|>10$ & $0,50 \leq R R M S E \leq 0,60$ \\
\hline Satisfactory & $0,65 \geq N S E \geq 0,5$ & $25 \geq|P B I A S|>15$ & $0,60 \leq R R M S E \leq 0,70$ \\
\hline Unsatisfactory & $N S E<0,50$ & $|P B I A S|<25$ & $R R M S E>0,70$ \\
\hline
\end{tabular}
\end{tabular}

Note: Adapted from [39].

Fig. 3 depicts the distribution of land use and soil type in the Manas watershed respectively. From Fig. 3A, the leading land use type in the Manas watershed is alamo switch grass $(29,40 \%)$, followed by spring wheat $(15,32 \%)$, Bermuda grass $(9,69 \%)$, alsike clover $(7,94 \%)$, oats $(5,54 \%)$, sideoats grama $(5,52 \%)$, altai wildrye $(4,48 \%)$, sorghum hay $(4,57 \%)$, rice $(3,25 \%)$, Kentucky bluegrass $(2,88 \%)$ and agricultural landgeneric $(2,41 \%)$. From Fig. 3B, the soil type distribution in the Manas watershed is as follows: Alpine meadow soil $(10,67 \%)$, Cultivated gray desert soil $(10,61 \%)$, Brown soil $(9,03 \%)$, ice $(8,61 \%)$, Dark felty soil $(7,94 \%)$, Dark chestnut soil $(6,58 \%)$, alpine frost soil $(5,96)$, Desert sand $(4,22 \%)$, Saline meadow soil $(4,20 \%)$, Crust soil $(4,09 \%)$, Salinized gray desert soil $(3,72 \%)$, Salinized Sierozem $(3,29 \%)$, Salinized moisture soil $(3,04 \%)$, Light chestnut soil $(2,49 \%)$, Chernozems $(2,42 \%)$ and Grey cinnamon soil $(2,38 \%)$. 

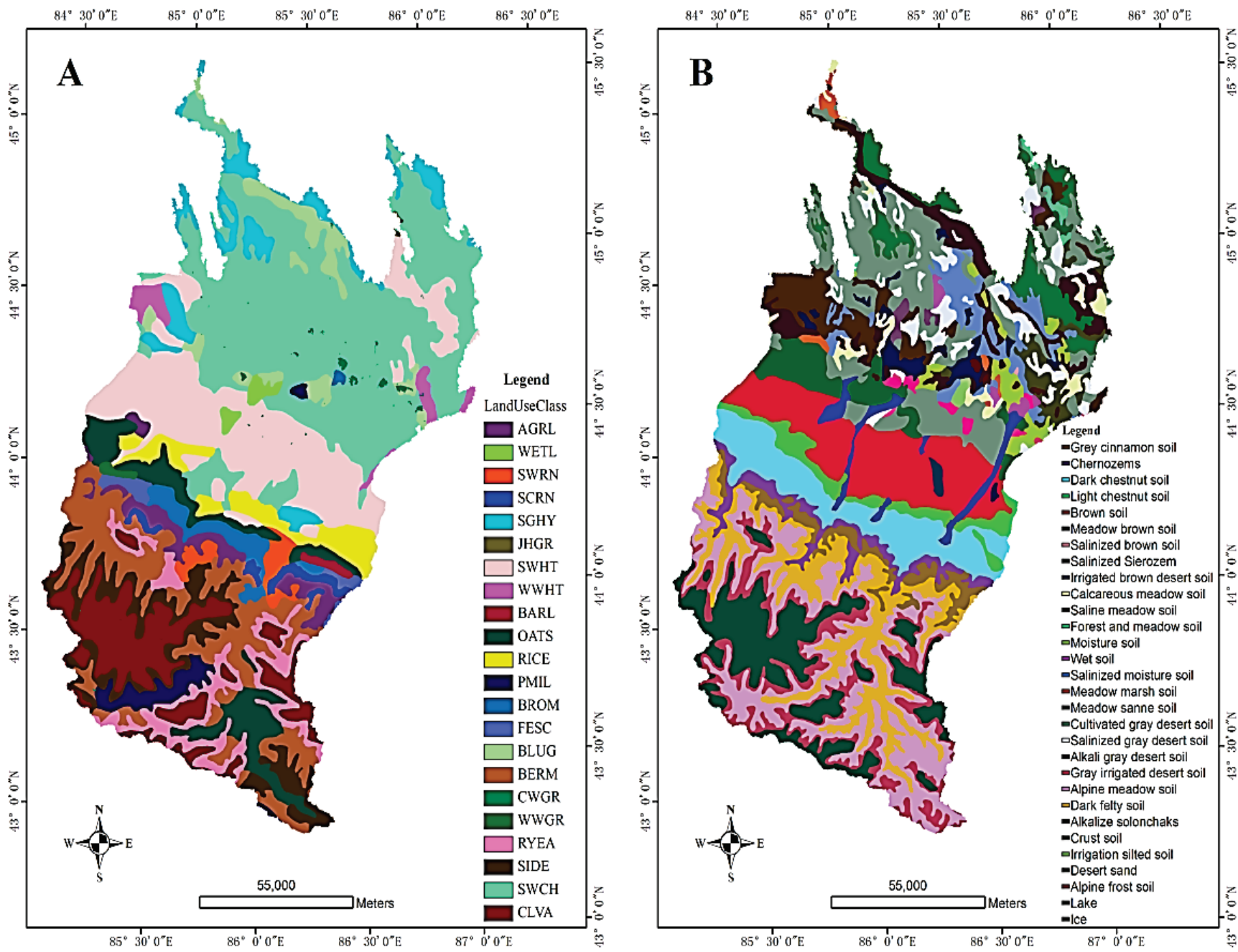

Figure 3 A) Soil distribution and B) Land use distribution for the watershed boundary and the river network of the Manas watershed, Xinjiang, China. AGRL, WETL, SWRN, SCRN, SGHY, JHGR, SWHT, WWHT, BARL, OATS, RICE, PMIL, BROM, FESC, BLUG, BERM, CWGR, WWGR, RYEA, SIDE, SWCH and CLVA stand for Agricultural Land-Generic, Wetlands-Mixed, Southwestern US (Arid) Range, Sweet Corn, Sorghum Hay, Johnson grass, Spring Wheat, Spring Wheat, Spring Barley, Oats, Rice, Pearl Millet, Smooth Brome grass, Tall Fescue, Kentucky Bluegrass, Bermuda grass,

Crested Wheatgrass, Western Wheatgrass, Altai Wildrye, Sideoats Grama, Alamo Switch grass, and Alsike Clover, respectively

Table 4 Performance statistics for flow simulations at Kenswat station

\begin{tabular}{|l|c|c|}
\hline \multicolumn{1}{|c|}{ Object } & $\begin{array}{c}\text { Calibration } \\
(1981 \div 1994)\end{array}$ & $\begin{array}{c}\text { Validation } \\
(1995 \div 2007)\end{array}$ \\
\hline RRMSE (Annual) & 0,050 & 0,227 \\
\hline PBIAS (Annual) & 0,453 & 1,312 \\
\hline NSE (Annual) & 0,937 & 0,951 \\
\hline$R^{2}$ (Annual) & 0,938 & 0,556 \\
\hline RRMSE (Monthly) & 0,014 & 0,241 \\
\hline PBIAS (Monthly) & 0,454 & 3,692 \\
\hline NSE (Monthly) & 0,998 & 0,943 \\
\hline$R^{2}$ (Monthly) & 0,999 & 0,942 \\
\hline
\end{tabular}

As described earlier, the hydrological simulation model for the Manas River Basin (MRB) was calibrated by annual stream flows at Kenswat and Hongshanzui stations using automatic calibration methods. The performance evaluation results for calibration and validation at both monthly and annual time steps are shown in Tabs. 4 and 5. From Tab. 4, Figs. 4 and 5, during the calibration and validation periods at Kenswat station, the maximum RRMSE (the ratio of root mean square error to the standard deviation) and PBIAS (percent bias) are 0,241 and 3,692 respectively, and the values of annual and monthly efficiency (NSE) are at least 0,951 and 0,943 respectively. For annual simulation, a maximum value of 0,227 for RRMSE, an NSE value of at least 0,95 , and a $P B I A S$ of less than $1,31 \%$ indicate a very good model performance; monthly simulation can also be judged as very good in this case.

From the results in Tab. 5, Figs. 6 and 7, the best performance of SWAT can be obtained at Hongshanzui station on monthly scale. Overall, during the calibration and validation periods at Hongshanzui station, the annual and monthly NSE values are at least 0,836 and 0,937 respectively; the maximum RRMSE and PBIAS are 0,418 and 4,8 respectively. For annual simulation, a maximum value of 0,418 for RRMSE, an NSE value of at least 0,836, and a PBIAS of less than 3,67\% indicate a very good model performance. Similarly, the CMADS-driven SWAT can also simulate the monthly stream excellently. 


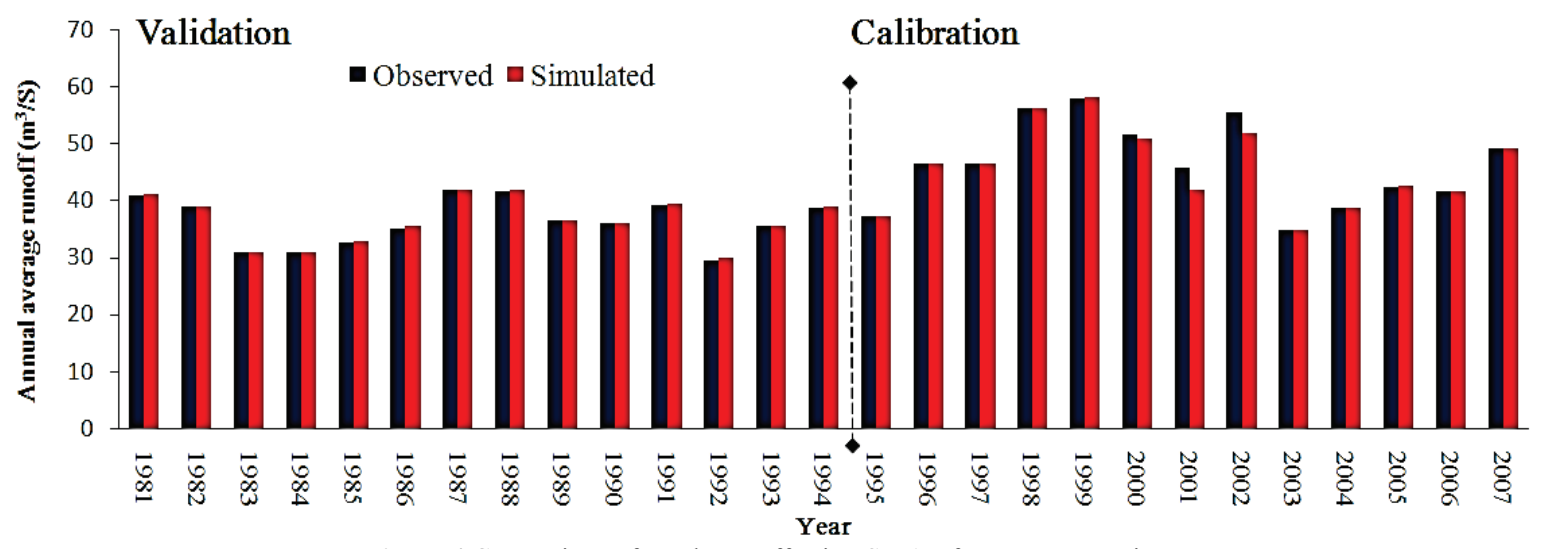

Figure 4 Comparison of yearly runoff using SWAT for Kenswat station

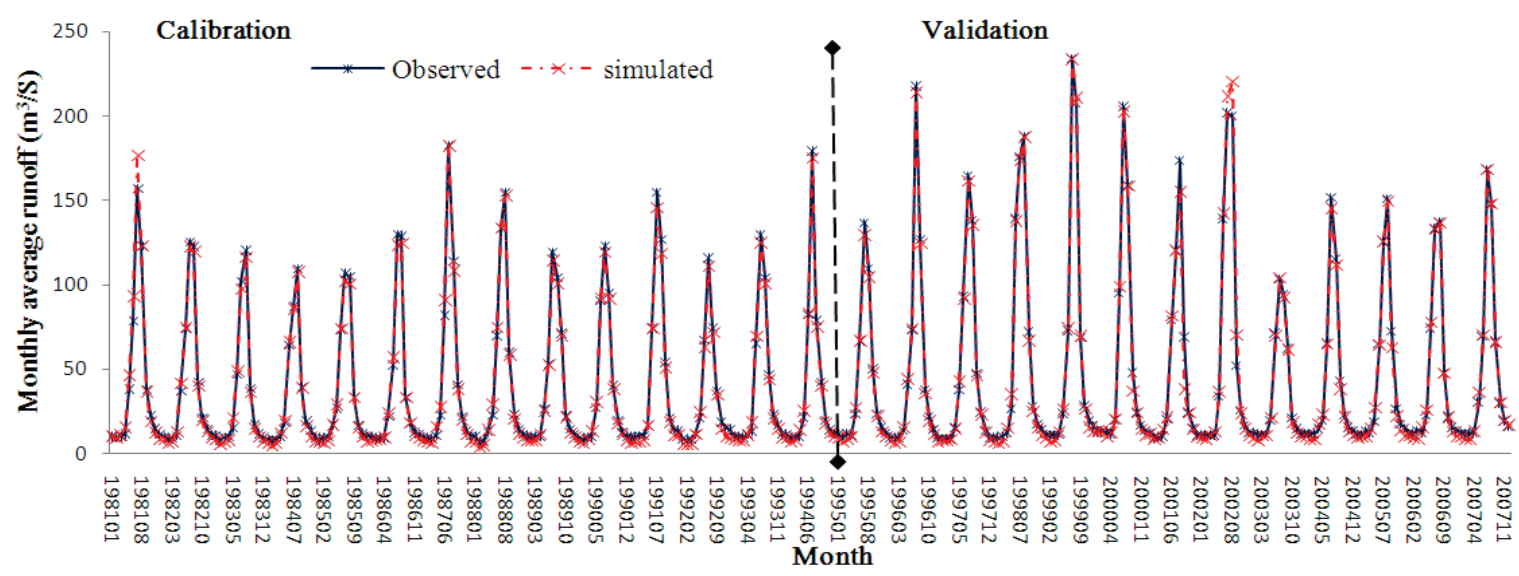

Figure 5 Comparison of monthly runoff using SWAT for Kenswat station

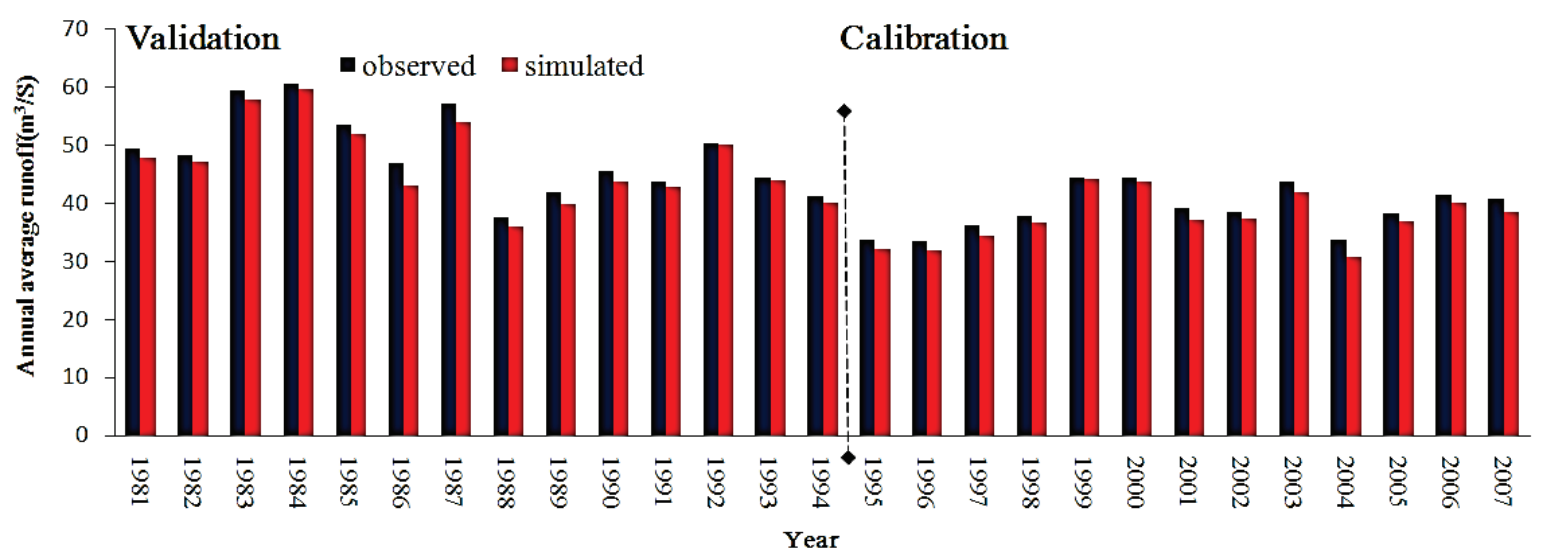

Figure 6 Comparison of annual runoff using SWAT for Hongshanzui station

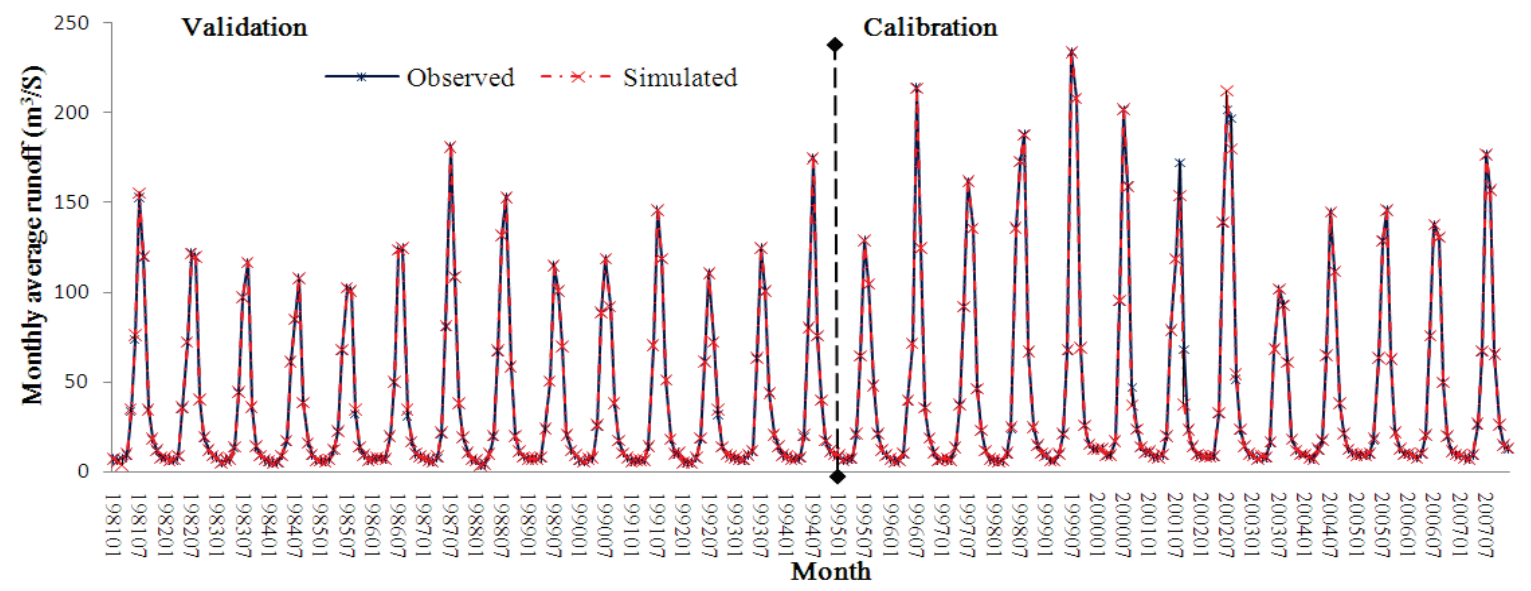

Figure 7 Comparison of monthly runoff using SWAT for Hongshanzui station 
Table 5 Performance Statistics for flow simulations at Hongshanzui station

\begin{tabular}{|l|c|c|}
\hline \multicolumn{1}{|c|}{ Object } & $\begin{array}{c}\text { Calibration } \\
(1981 \div 1994)\end{array}$ & $\begin{array}{c}\text { Validation } \\
(1995 \div 2007)\end{array}$ \\
\hline RRMSE (Annual) & 0,418 & 0,292 \\
\hline PBIAS (Annual) & 3,670 & 3,450 \\
\hline NSE (Annual) & 0,836 & 0,922 \\
\hline$R^{2}$ (Annual) & 0,983 & 0,927 \\
\hline RRMSE (Monthly) & 0,086 & 0,084 \\
\hline PBIAS (Monthly) & 3,400 & 4,810 \\
\hline NSE (Monthly) & 0,997 & 0,937 \\
\hline$R^{2}$ (Monthly) & 0,993 & 0,938 \\
\hline
\end{tabular}

\section{Conclusion}

To improve the simulation effects of SWAT in ungauged area and assess the model performance in areas with high glacier recharge rate, this study carried out runoff simulation and validation of the Manas River Basin (MRB) through the CMADS-driven SWAT model. From the perspective of atmospheric forcing field uncertainty, we firstly introduced some technical methods such as parameter sensitivity analysis, parameter optimization calibration and so on, and then built the localization mode of the Manas River Basin (MRB) based on the CMADSdriven SWAT model. We finally achieved some conclusions as follows:

(1) After parameter sensitivity analysis and parameter calibration and validation with the temperature index method, SWAT was proved to be applicable in areas with high glacier recharge rate. However, considering the climate change and human impacts in the Manas River Basin (MRB), it still needs to be continuously verified whether the localization mode can be suitable for this basin.

(2) This study introduced CMADS to drive SWAT for the model localization and carried out runoff simulation on two stations (Kenswat and Hongshanzui) in the Manas River Basin (MRB). It was found that the CMADS-driven SWAT model could reproduce water resources cycle of the Manas River Basin (MRB) no matter on monthly scale or annual scale, indicating the good localization effect of CMADS for SWAT.

This study used CMADS to drive SWAT, and efficiently simulated the Manas River Basin (MRB) with high glacier recharge rate. The results can greatly promote the study of SWAT in the field of large-scale water resources assessment in alpine areas. Besides, it is more convenient for researchers to use SWAT to assess and analyze land surface components with high resolution in the East Asian areas (in the scope of CMADS).

\section{Acknowledgement}

This study was jointly supported by National Key Research and Development Project (2016YFC0402208, 2016YFC0401903, 2016YFC0400903, 2016YFC0402204, 2016YFC0402201), National Key Technology R\&D Program (2015BAB07B03), and State Key Laboratory of Simulation and Regulation of Water Cycle in River Basin (2016CG05).

\section{References}

[1] Ghaffari, G.; Keesstra, S. D.; Ghodousi, J.; Ahmadi. H. SWAT-simulated hydrological impact of land-use change in the Zanjanrood Basin, Northwest Iran. // Hydrological Process. 24, 7(2010), pp. 892-903. DOI: 10.1002/hyp.7530

[2] Volk, M.; Bosch, D.; Nangia, V.; Narasimhan, B. SWAT: Agricultural water and nonpoint source pollution management at a watershed scale. // Agricultural Water Management. 175(2016), pp. 1-3. DOI: 10.1016/j.agwat.2016.06.013

[3] Pereira, D. D. R.; Martinez, M. A.; Pruski F. F.; da Silva, D. D. Hydrological simulation in a basin of typical tropical climate and soil using the SWAT model part I: Calibration and validation tests. // Journal of Hydrology: Regional Studies. 7(2016), pp. 14-37.

[4] Galván, L.; Olías, M.; Cánovas, C. R.; Sarmiento A. M.; Nieto, J. M. Hydrological modeling of a watershed affected by acid mine drainage (Odiel River, SW Spain). Assessment of the pollutant contributing areas. // Journal of Hydrology. 540(2016), pp. 196-206. DOI: 10.1016/j.jhydrol.2016.06.005

[5] Özcana, Z.; Kentelb, E.; Alpa, E. Determination of unit nutrient loads for different land uses in wet periods through modelling and optimization for a semi-arid region. // Journal of Hydrology. 540(2016), pp. 40-49. DOl: 10.1016/j.jhydrol.2016.05.074

[6] Choa, K. H.; Pachepsky, Y. A.; Minjeong, K; JongCheol, P; Mi-Hyun, P.; Young, M.; Kime, J. H.; Kimd, M.; Kime, J. W.; Kimd, J. H. Modeling seasonal variability of fecal coliform in natural surface waters using the modified SWAT. // Journal of Hydrology. 535(2016), pp. 377-385. DOI: 10.1016/j.jhydrol.2016.01.084

[7] Zhang, Y. Q.; Chen, Y. C.; Ge, J. Impacts of climate change on stream flows under RCP scenarios: A case study in Xin River Basin, China. // Atmospheric Research. 178179 (2016), pp. 521-534. DOI: 10.1016/j.atmosres.2016.04.018

[8] Li, J. Z.; Li. G. Q.; Zhou S. H.; Chen, F. L. Quantifying the effects of land surface change on annual runoff considering precipitation variability by SWAT. // Water Resources Management. 30, 3(2016), pp. 1071-1084. DOI: $10.1007 / \mathrm{s} 11269-015-1211-8$

[9] Walters, K. M.; Babbar-Sebens, M. Using climate change scenarios to evaluate future effectiveness of potential wetlands in mitigating high flows in a Midwestern U.S. watershed. // Ecological Engineering. 89(2016), pp. 80-102. DOI: 10.1016/j.ecoleng.2016.01.014

[10] Meng, X. Y.; Yu D. L.; Liu, Z. H. Energy Balance-Based SWAT Model to Simulate the Mountain Snowmelt and Runoff - Taking the Application in Juntanghu Watershed (China) as an Example. // Journal of Mountain Sciences. 12, 2(2015), pp. 368-381. DOI: 10.1007/s11629-014-3081-6

[11] Zhang, A.; Liu, W.; Yin, Z.; Fu G.; Zheng, C. How will climate change affect the water availability in the Heihe River Basin, Northwest China? // Journal of Hydrometeorology. 17, 5(2016), pp. 1517-1542. DOI: 10.1175/JHM-D-15-0058.1

[12] Sharma, S.; Shrestha, A.; Mclean, C. E. Impact of global climate change on stream low flows in a hydraulic fracking affected watershed. // Journal of Water Resource and Hydraulic Engineering. 5, 1(2016), pp. 1-19. DOI: 10.5963/JWRHE0501001

[13] Shrestha, B.; Cochrane, T.A.; Caruso, B. S.; Arias, M. E.; Piman, T. Ucertainty in flow and sediment projections due to future climate scenarios for the 3S Rivers in the Mekong Basin. // Journal of Hydrology. 540(2016), pp. 1088-1104. DOI: 10.1016/j.jhydrol.2016.07.019

[14] Kliment, Z.; Kadlec, J.; Langhammer, J. Evaluation of suspended load changes using AnnAGNPS and SWAT semi-empirical erosion models. // Catena. 73, 3(2008), pp. 286-299. DOI: 10.1016/j.catena.2007.11.005

[15] Ouyang, W.; Jiao, W.; Li, X.; Giubilato, E.; Critto, A. Long-term agricultural non-point source pollution loading dynamics and correlation with outlet sediment 
geochemistry. // Journal of Hydrology. 540(2016), pp. 379385. DOI: 10.1016/j.jhydrol.2016.06.043

[16] Rodriguez-Blanco, M. L.; Arias, R.; Taboada-Castro, M. M.; Nunes, J. P.; Keizer, J. J.; Taboada-Castro. M. T. Sediment yield at catchment scale using the SWAT (Soil and Water Assessment Tool) model. // Soil Science. 181, 7(2016), pp. 326-334. DOI: 10.1097/SS.0000000000000158

[17] Roth, V.; Lemann, T. Comparing CFSR and conventional weather data for discharge and soil loss modelling with SWAT in small catchments in the Ethiopian Highlands. // Hydrology and Earth System Sciences. 20(2016), pp. 921934. DOI: 10.5194/hess-20-921-2016

[18] Li, T.; Gao,Y. Runoff and sediment yield variations in response to precipitation changes: A case study of Xichuan watershed in the loess plateau, China. // Water, 7, 10(2015), pp. 5638-5656. DOI: 10.3390/w7105638

[19] Luo, Y.; Arnold, J.; Allen, P.; Chen, X. Base flow simulation using SWAT model in an inland river basin in Tianshan Mountains, Northwest China. // Hydrology and Earth System Sciences. 16, 4(2012), pp. 1259-1267. DOI: 10.5194/hess-16-1259-2012

[20] Ji, X.; Luo, Y. The influence of precipitation and temperature input schemes on hydrological simulations of a snow and glacier melt dominated basin in Northwest China. // Hydrol. Hydrology and Earth System Sciences. 10, 1(2013), pp. 807-853. DOI: 10.5194/hessd-10-807-2013

[21] Ling, H.; Xu, H.; Shi, W.; Zhang, Q. Regional climate change and its effects on the runoff of Manas River,Xinjiang, China. // Environmental Earth Sciences. 64, 8(2011), pp. 2203-2213. DOI: 10.1007/s12665-011-1048-2

[22] Tang, X. L.; Li, J. F.; Lv, X.; Long, H. L. Analysis of the characteristics of runoff in Manasi River Basin in the past 50 years. // Procedia Environmental Sciences. 13(2012), pp. 1354-1362. DOI: 10.1016/j.proenv.2012.01.128

[23] Luo, Y.; Arnold, J.; Liu, S.; Wang, X.; Chen, X. Inclusion of glacier processes for distributed hydrologicalmodeling at basin scale with application to a watershed in Tianshan Mountains, northwest China. // Journal of Hydrology. 477 (2013), pp. 72-85. DOI: 10.1016/j.jhydrol.2012.11.005

[24] Ling, H.; Xu, H.; Fu, J.; Liu, X. Surface runoff processes and sustainable utilization of water resources in Manas River Basin, Xinjiang, China. // Journal of Arid Land. 4, 3(2012), pp. 271-280. DOI: 10.3724/SP.J.1227.2012.00271

[25] Feng, Y. X.; Luo, G. P.; Lu, L.; Zhou, D. C.; Han, Q. F.; Xu, W. Q.; Yin, C. Y.; Zhu, L. D.; Li, Y. Z.; Li, C. F. Effects of land use change on landscape pattern of the Manas River watershed in Xinjiang, China. // Environmental Earth Sciences. 64, 8(2011), pp. 2067-2077. DOI: 10.1007/s12665-011-1029-5

[26] Arnold, J. G.; Srinivasan, R.; Muttiah, R. S.; Williams, J. R. Large area hydrologic modeling and assessment part I: model development. // Journal of the American Water Resources Association. 34, 1(1998), pp. 73-89. DOI: 10.1111/j.1752-1688.1998.tb05961.x

[27] Srinivasan, R.; Ramanarayanan, T. S.; Arnold, J. G.; Bednarz, S. T. Large area hydrologic modeling and assessment part II: model application. // Journal of the American Water Resources Association. 34, 1(1998), pp. 91-101. DOI: 10.1111/j.1752-1688.1998.tb05962.x

[28] Arnold, J. G.; Williams, J. R.; Maidment, D. Continuoustime water and sediment routing model for large basins. // Journal of Hydrologic Engineering. 121, 2(1995), pp. 171183. DOI: 10.1061/(ASCE)0733-9429(1995)121:2(171)

[29] Sloan, P. G.; Morre, I. D. Modeling surface and subsurface stormflow on steeply-sloping forested watersheds. // Water Resources Research. 20, 12(1984), pp. 1815-1822. DOI: 10.1029/WR020i012p01815

[30] Green, W. H.; Ampt, G. A. Studies on soil physics, 1. The flow of air and water through soils. // Journal of Agricultural Sciences. 4, 1(1911), pp. 1-24.
[31] Boughton, W. C. A review of the USDA SCS curve number method. // Australian Journal of Soil Research. 27, 3(1989), pp. 511-523. DOI: 10.1071/SR9890511

[32] Priestley, C.H.B.; Taylor, R.J. On the assessment of surface heat flux and evaporation using large-scale parameters. // Monthly Weather Review, 100, 2(1972), pp. 81-92. DOI: 10.1175/1520-0493(1972)100<0081:OTAOSH>2.3.CO;2

[33] Monteith, J. L. Evaporation and the environment. // In The state and movement of water in living organisms. // XIXth Symposium. Soc. for Exp. Biol / Swansea. 19, (1965), pp. 205-234.

[34] Hargreaves, G. H.; Samani, Z. A. Reference crop evapotranspiration from temperature. // Applied Engineering in Agriculture. 1, 2(1985), pp. 96-99. DOI: $10.13031 / 2013.26773$

[35] Wang, H.; Meng, X.; Cai, S.; Zhang, X.; Lei, X.; Leng, G.; Shi, C.; Liu, S. The China Meteorological Assimilation Driving Datasets for the SWAT model (CMADS) and it's Application in the Heihe River Basin in China. Preprints 2016, 2016120091. DOI: 10.20944/preprints201612.0091.v1

[36] McKay, M. D.; Beckman, R. J.; Conover, W. J. A comparison of three methods for selecting values of input variables in the analysis of output from a computer code. // Technometrics. 21, 2(1979), pp. 239-245. DOl: 10.1080/00401706.1979.10489755

[37] Abbaspour, K. C.; Yang, J.; Maximov, I.; Siber, R.; Bogner, K.; Mieleitner, J.; Zobrist, J.; Srinivasan, R. Modelling hydrology and water quality in the prealpine/alpine Thur watershed using SWAT. // Journal of Hydrology. 333, 2-4(2007), pp. 413-430. DOI: 10.1016/j.jhydrol.2006.09.014

[38] Grusson, Y.; Sun, X. L.; Gascoin, S.; Sauvage, S.; Raghavan, S.; Anctile, F.; José-Miguel Sáchez-Pérez. Assessing the capability of the SWAT model to simulate snow, snow melt and streamflow dynamics over an alpine watershed. // Journal of Hydrology. 531, 3(2015), pp. 574588. DOI: 10.1016/j.jhydrol.2015.10.070

[39] Moriasi, D.; Arnold, J. G.; Vanliew, M. W.; Bingner, R. L.; Harmel, R. D.; Veith,T. L. Model Evaluation Guidelines for Systematic Quantification of Accuracy in Watershed Simulations. // Transactions of the ASABE (American Society of Agricultural and Biological Engineers). 50(2007), pp. 885-900. DOI: 10.13031/2013.23153

[40] Nash, J. E.; Sutcliffe. J. V. River flow forecasting through conceptual models: Part I - A discussion of principles. // Journal of Hydrology. 10, 3(1970), pp. 282-290. DOI: 10.1016/0022-1694(70)90255-6

[41] Gupta, H. V.; Sorooshian, S.; Yapo, P. O. Status of automatic calibration for hydrologic models: Comparison with multilevel expert calibration. // Journal of Hydrologic Engineering. 4, 2(1999), pp. 135-143. DOl: 10.1061/(ASCE)1084-0699(1999)4:2(135)

\section{Authors' addresses}

\section{Xianyong Meng, Ph.D.}

State Key Laboratory of Simulation and Regulation of Water Cycle in River Basin \& China Institute of Water Resources and Hydropower Research,

No. 1 Fuxing Road, Beijing, 100038, P. R. China E-mail: mxy@iwhr.com

\section{Hao Wang, Ph.D., China Academy of Engineering}

(Corresponding author)

State Key Laboratory of Simulation and Regulation of Water Cycle in River Basin \& China Institute of Water Resources and Hydropower Research,

No. 1 Fuxing Road, Beijing, 100038, P. R. China.

E-mail:wanghao@iwhr.com 
Xiaohui Lei, Ph.D., Professor

(Corresponding author)

State Key Laboratory of Simulation and Regulation of Water Cycle

in River Basin \& China Institute of Water Resources and

Hydropower Research,

No. 1 Fuxing Road, Beijing, 100038, P. R. China

E-mail: 1xh@iwhr.com

Siyu Cai, Ph.D.

State Key Laboratory of Simulation and Regulation of Water Cycle in River Basin \& China Institute of Water Resources and

Hydropower Research,

No. 1 Fuxing Road, Beijing, 100038, P. R. China

E-mail: csy@iwhr.com

Hongjing $\mathrm{Wu}$, Ph.D., Research associate

NRPOP Lab, Faculty of Engineering and Applied Science,

Memorial University of Newfoundland,

St. John's, NL, Canada | A1B 3X5

ZIP code: T 7097495201

E-mail: hjwu@mun.ca

Xiaonan Ji, Ph.D.

State Key Laboratory of Desert and Oasis Ecology,

Xinjiang Institute of Ecology and Geography,

Chinese Academy of Sciences,

Urumqi, 830046, P. R. China

E-mail: dsslab@126.com

Jianhua Wang, Ph.D., Professor

State Key Laboratory of Simulation and Regulation of Water Cycle in River Basin \& China Institute of Water Resources and

Hydropower Research,

No. 1 Fuxing Road, Beijing, 100038, P. R. China

E-mail: wjh@iwhr.com 